\title{
Factors Affecting Forage Quality 1
}

\section{A. T. Adesogan, L. E. Sollenberger, Y.C. Newman, and J.M.B. Vendramini ${ }^{2}$}

\section{Introduction}

Forage testing is necessary because forage quality varies considerably due to several factors, including differences in forage genotype, maturity, season, and management. An understanding of factors affecting forage quality will help producers anticipate and plan for changes in forage quality.

When forage quality is low, forages alone may not support desired rates of animal performance. In such cases, it is necessary to provide livestock with supplements for protein and energy.

\section{What is Forage Quality?}

Animal performance, whether growth or milk production, depends upon the animal's potential for production, as well as on how much dry matter (DM) the animal eats and the nutritive value of the DM the animal consumes. Therefore, the two forage-related factors that determine animal performance are forage intake and forage nutritive value. Collectively, these

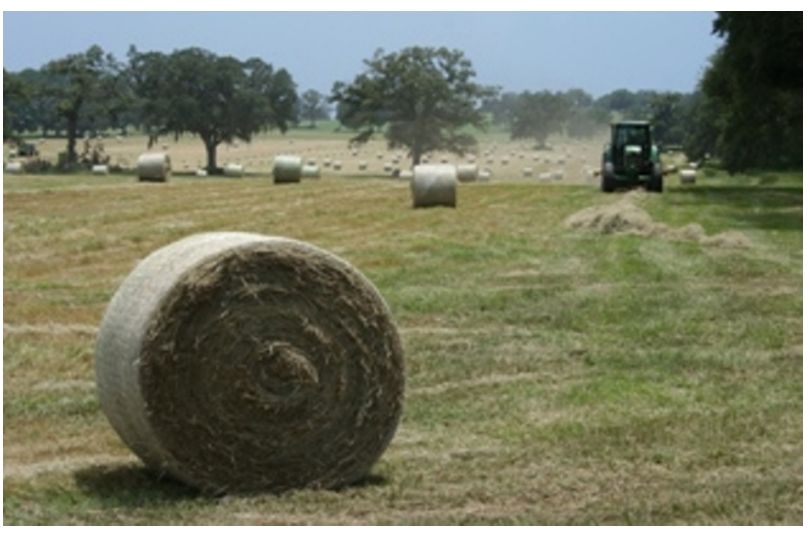

Figure 1. Bahiagrass field in Florida. Credits: Y.C. Newman

factors determine the quality of the forage. When forage is fed without restriction as the sole feed, forage quality can be an excellent predictor of animal performance.

\section{Factors Affecting Forage Intake}

Forage intake is affected by a range of factors, including the amount of forage available and characteristics of the forage consumed, as well as the

1. This document is SS-AGR-93, one of a series of the Agronomy Department, Florida Cooperative Extension Service, Institute of Food and Agricultural Sciences, University of Florida. First published in EDIS in June 2002. Original authors were A. T. Adesogan, associate professor, Department of Animal Sciences; L. E. Sollenberger, professor, Agronomy Department; and J. E. Moore, professor emeritus, Department of Animal Sciences. This publication was revised in April 2006 and in June 2009. This publication is a part of the Florida Forage Handbook, an electronic publication of the Agronomy Department. For more information, contact the editor of the Florida Forage Handbook, Yoana Newman, ycnew@ufl.edu. Visit the EDIS Web site at http://edis.ifas.ufl.edu.

2. A. T. Adesogan, associate professor, Department of Animal Sciences; L. E. Sollenberger, professor, Agronomy Department; Y.C. Newman, assistant professor, Agronomy Department, and J.M.B. Vendramini, assistant professor, Agronomy Department, Range Cattle Research and Education Center--Ona, FL, Florida Cooperative Extension Service, Institute of Food and Agricultural Sciences, University of Florida, Gainesville, FL.

The use of trade names in this publication is solely for the purpose of providing specific information. UF/IFAS does not guarantee or warranty the products named, and references to them in this publication does not signify our approval to the exclusion of other products of suitable composition.

The Institute of Food and Agricultural Sciences (IFAS) is an Equal Opportunity Institution authorized to provide research, educational information and other services only to individuals and institutions that function with non-discrimination with respect to race, creed, color, religion, age, disability, sex, sexual orientation, marital status, national origin, political opinions or affiliations. U.S. Department of Agriculture, Cooperative Extension Service, University of Florida, IFAS, Florida A. \& M. University Cooperative Extension Program, and Boards of County Commissioners Cooperating. Interim Dean Millie Ferrer. 
animal's gut capacity, performance level, health, genotype and social hierarchy. Environmental factors also affect forage intake, including prevailing temperature and humidity. Management factors -such as stocking rate, type and level of supplementation, feeding frequency, and availability of water and feed -- also affect forage intake.

Additionally, forage intake is affected by forage availability and by many characteristics of forages, such as particle size of stored forages and amounts of fiber, protein, and minerals in the DM. How fast undigested DM passes through the animal also affects an animal's forage intake. Molds and any other substances that make the forage unpalatable also affects livestock intake of hay. Intake of pasture forage is also affected by the nature of the sward. Accumulations of dead forage or manure on pasture will decrease intake, and a dense, leafy canopy will increase forage intake.

"Voluntary forage intake" is used to describe how much forage DM an animal will consume when adequate amounts of palatable forage are available, when no supplements of protein and energy are fed to the animal, and when adequate minerals are available -- either in the forage or as supplements. Energy and protein supplements may either increase or decrease livestock forage intake, depending upon the composition of the forage and the composition and amount of supplement being fed to the livestock.

\section{Factors Affecting Forage Nutritive Value}

Forage nutritive value is primarily determined by concentrations of crude protein (CP) and "available" energy in the forage. For many years total digestible nutrients (TDN) has been used as an overall measure of available energy in forages. In the past 20 years, however, measurements of digestible forage, metabolizable forage, and net energy of forage have increasingly been used. However, TDN is still an acceptable and easily understood measure of nutritive value, particularly for beef cattle.

Forage quality is affected most by variations in forage genotype, maturity, season, and management. Other "anti-quality" factors may be encountered occasionally; these factors are described below, under heading 5, Anti-Quality Factors Affecting Forage.

\section{Genotype}

Legumes generally have a higher quality than grasses. Legumes have higher CP concentrations and a higher intake by livestock due to a higher percentage of rapidly digestible leaves. However, TDN concentrations of legumes and cool-season grasses are similar. Generalizations about quality of grasses are risky, but temperate or cool-season grasses, such as rye and ryegrass, often have higher quality than tropical or warm-season grasses, such as bermudagrass and bahiagrass. However, there is much variation in forage quality within and among grass genera.

\section{Maturity}

The stage of forage regrowth at time of utilization - whether as hay, haylage or grazing has a major influence on forage quality. Forage-regrowth stage is determined by the number of days between harvests for hay or haylage and by the rest period in rotational grazing.

Forage quality begins to decline as soon as forages start to regrow due to the accumulation of stems and deposition of poorly digested lignin in both leaves and stems. Therefore, forage quality generally declines with increasing length of the interval between harvests of stored forages or with longer rest periods in rotational grazing.

Maturity of legumes and cool-season grasses can be assessed by determining the reproductive stage of growth. For warm-season grasses, however, weeks of regrowth is a better indicator of maturity because flowering may begin shortly after regrowth begins.

Table 1 shows a decline in digestibility and crude protein of Coastal bermudagrass after week five (35 days) of regrowth. The information in this table indicates that harvesting Coastal bermudagrass at intervals greater than five weeks will reduce the quality of this forage.

Table 2 provides examples of the effects of forage genotype and maturity on the quality of typical forage grasses in Florida. Each value represents 
several cuttings made from different cultivars in different years. These values are a general reference point. These data suggest that digitgrass and limpograss tend to have higher quality than bahiagrass, bermudagrass, and stargrass, especially at later stages of maturity. These differences often affect voluntary intake, as well.

With respect to maturity effects on perennial grasses, the most dramatic difference is the decrease in voluntary intake between six and eight weeks. These data and others show that after eight weeks regrowth, forage quality will generally be less than needed for livestock maintenance. Exceptions are digitgrass and limpograss, which maintain a somewhat higher TDN when mature than do the other grasses. Consequently, limpograss and digitgrass are excellent forages for fall stockpiling. However, mature limpograss and digitgrass often are low in $\mathrm{CP}$ and require protein supplementation for maximum utilization.

\section{Season}

Seasonal effects on forage quality have been noted in grazing trials in Florida where forage regrowth intervals were kept constant. A "summer slump" was observed in that gains of grazing cattle were less during the summer than in spring and fall. That this slump in cattle weight gain during the summer is an effect of environment on forages -- and not due to the effect of the environment on animals -was suggested by a direct comparison of bahiagrass with dwarf elephantgrass.

The summer slump was dramatic with bahiagrass, but not apparent with elephantgrass even though similar cattle grazed adjacent paddocks of the two grasses. Summer slumps in quality of warm-season grasses have been observed with hay harvested after similar regrowth intervals on different dates throughout the growing season (Table 3). Summer regrowth may have lower quality because high temperature increases lignin deposition, and high rainfall increases growth rates and maturation of the forage.

In the case of hay made in Florida, the negative effects of season and maturity on forage quality may be additive. Spring harvests are made generally after short regrowth periods while summer harvests are made after long regrowth periods because of heavy summer rainfall that delays harvests. Therefore, the quality of bermudagrass hay is highest when harvested in the spring or early summer.

\section{Management}

\section{Pre-Harvest Management}

Pre-harvest management for maximum quality of hay or silage involves weed control and frequent cutting. (See discussion above under heading 2, Maturity.) Some producers harvest every four or five weeks throughout the season, making either hay or silage, depending on rainfall.

\section{Post-Harvest Management}

The quality of hay or silage will never increase during harvesting and storage, but post-harvest decreases in quality can be minimized by careful management. Post-harvest management requires avoiding rain damage, as well as proper curing of hay to less than 15 percent moisture or wilting of silage to 60 - 70 percent moisture, promptly sealing silos and wrapping haylages, and minimizing losses during storage. Leaching of nutrients from weathering decreases forage nutritive value. Therefore, hay bales should be stored under a barn or a tarp whenever possible.

Growth of molds may also decrease palatability and, therefore, reduce livestock intake of forage. Additionally, molds may lead to production of mycotoxins, which can impair animal health and also affect human health negatively. To avoid mold growth, stored forages should be harvested and conserved at the recommended moisture concentrations. In addition, silage or haylage plastic should be maintained properly; any holes should be promptly sealed with silage tape. Silages should be packed at a density of approximately 15 pounds/ $\mathrm{ft}^{3}$ and fed out at a rate that prevents heating. Application of additives containing propionic acid or Lactobacillus buchneri inoculants can also prevent the growth of molds. 


\section{Management of Grazed Pastures}

For maximum quality, pastures should be managed to maintain a leafy canopy that is free of weeds and dead herbage and is grazed uniformly without many ungrazed patches. There is much controversy about how to achieve such a target. Some grazing experts contend that frequent rotation is desirable. Others feel that if stocking rate is matched carefully to forage availability, then frequent rotation offers little advantage

The management requirements of a particular forage and the objectives of the livestock operation often are the most important factors influencing choice of rotation frequency. In addition, over-grazing should be avoided because lack of available forage will have a major negative impact on animal performance, regardless of forage nutritive value and potential quality.

Generally, fertilizer application has little effect on forage quality except that $\mathrm{CP}$ will be increased for a period of time following $\mathrm{N}$ fertilization. If forage $\mathrm{CP}$ is low in unfertilized grass, then $\mathrm{N}$ fertilizer application will often increase forage $\mathrm{CP}$ and contribute to improved forage intake and animal performance.

\section{Anti-Quality Factors}

Examples of anti-quality factors in commonly grazed or fed Florida forages are noxious weeds, nitrates, prussic acid, ergot alkaloids, insect infestation and unusually wet growing areas.

Nitrate or prussic acid accumulation can occur in certain forages after stressful periods, such as drought, frost, hail, and herbicide or fertilizer injury. Nitrate accumulation is common in corn, rye, sorghum, sudangrass and alfalfa, and prussic acid accumulates in millet, sorghum and sudangrass. Both of these compounds - nitrate and prussic acid -- can limit oxygen transfer in the blood of livestock. Therefore the accumulation of these compounds in forage is dangerous to livestock. If forages have undergone a stressful period as described above, forage samples should be sent for nitrate or prussic-acid testing before the forage is fed to livestock. Proper ensiling generally reduces concentrations of these compounds to safe levels, but volatile toxic gases are released during the ensiling process. Therefore, workers should be careful when handling ensiled forages.

Ergot alkaloids have also been observed in a few cases on bermudagrass in Florida, as in Mexico, Texas, and Oklahoma. Problems such as tremors associated with ingestion of ergot alkaloids can be avoided by maintaining a four-to-five-week cutting interval for bermudagrass, interseeding with legumes or other grasses, and diluting the toxin with nontoxic forages and supplements.

In some cases, insects can defoliate forages, thus decreasing forage quality. Additionally, cattle grazing improved forages grown under very wet conditions (i.e., standing water) are observed to have low rates of performance, but the reasons for this effect are not well defined.

\section{Implications}

Forage quality varies widely due to variations in forage genotype, maturity, season, management, and anti-quality components. Because of all these factors and their interactions, tables of forage quality and nutritive value are unlikely - by themselves - to provide useful information about a particular forage. Therefore, be sure to test forages frequently, using forage samples that are taken carefully to insure that the samples are representative of forage being consumed by livestock.

\section{Additional Information}

Newman, Yoana C. and Adegbola T. Adesogan, Joao Vendramini and Lynn Sollenberger. 2009. Defining Forage Quality, EDIS Publication SS-AGR-322, http://edis.ifas.ufl.edu/AG332. Department of Agronomy, Institute of Food and Agricultural Sciences, University of Florida.

Vendramini, J.M. and M.S. Silveira, J. D. Arthington, and A. R. Blount. 2001 and 2009. Forage Testing, EDIS Publication SS-AGR-63, http://edis.ifas.ufl.edu/document_aa192. Department of Agronomy, Institute of Food and Agricultural Sciences, University of Florida. 
Table 1. Nutrient Composition of Coastal Bermudagrass as Affected by Maturity. (Adapted from Mandevbu et al., 1999.)

\begin{tabular}{|c|c|c|c|c|}
\hline \multirow[b]{2}{*}{$\begin{array}{l}\text { Age of Grass } \\
\text { (Weeks) }\end{array}$} & Digestibility & Crude Protein & ADF & Lignin \\
\hline & \multicolumn{4}{|c|}{ 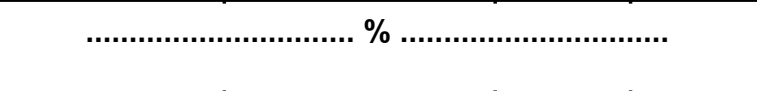 } \\
\hline 4 & 60 & 18 & 29 & 4 \\
\hline 5 & 59 & 18 & 30 & 4 \\
\hline 6 & 56 & 16 & 31 & 5 \\
\hline 7 & 53 & 13 & 33 & 6 \\
\hline
\end{tabular}

Table 2. Effects of Grass and Maturity on Forage Quality. ${ }^{a}$

\begin{tabular}{|c|c|c|c|c|c|c|}
\hline \multirow[b]{2}{*}{ Grass } & \multicolumn{3}{|c|}{$\mathrm{TDN}^{\mathrm{b}}$} & \multicolumn{3}{|c|}{ Voluntary Intake ${ }^{\mathrm{C}}$} \\
\hline & 4 weeks & 6 weeks & 8 weeks & 4 weeks & 6 weeks & 8 weeks \\
\hline Bahia & 56 & 55 & 54 & 2.3 & 2.1 & 1.7 \\
\hline Bermuda & 57 & 52 & 44 & 2.3 & 2.2 & 1.8 \\
\hline Star & 60 & 53 & 49 & 2.4 & 2.5 & 2.1 \\
\hline Digit & 60 & 58 & 57 & 2.5 & 2.7 & 2.2 \\
\hline Limpo & 63 & 63 & 56 & 2.5 & 2.3 & 2.2 \\
\hline \multicolumn{7}{|c|}{$\begin{array}{l}{ }^{a} \text { Adapted from Brown and Kalmbacher, p. } 79-87 \text {, in } 47 \text { th Annual Florida Beef Cattle Short } \\
\text { Course Proceedings, May } 1998 \text { (summary of research with sheep by J.E. Moore and W.R. } \\
\text { Ocumpaugh). } \\
\text { b Total Digestible Nutrients, percentage of dry matter. } \\
{ }^{c} \text { Intake of dry matter expressed as percentage of body weight. } \\
{ }^{\mathrm{d}} \text { Voluntary TDN intake relative to maintenance requirement; } 1.0 \text { = maintenance. }\end{array}$} \\
\hline
\end{tabular}

Table 3. Quality of Coastal Bermudagrass Hay Harvested at Different Maturities and Seasons ${ }^{a}$.

\begin{tabular}{|c|c|c|c|c|c|c|}
\hline \multirow[t]{2}{*}{ Item } & \multirow{2}{*}{$\begin{array}{l}\text { Weeks } \\
\text { Of Regrowth }\end{array}$} & \multicolumn{5}{|c|}{ Harvest Date } \\
\hline & & $6 / 14$ & $7 / 12$ & $8 / 9$ & $9 / 6$ & $10 / 4$ \\
\hline \multirow[t]{3}{*}{ TDN, $\%^{\mathrm{b}}$} & 4 & 55 & 57 & 52 & 53 & 46 \\
\hline & 6 & 52 & 51 & 47 & 49 & 48 \\
\hline & 8 & 52 & 51 & 46 & 47 & 44 \\
\hline \multirow[t]{3}{*}{$\mathrm{QI}^{\mathrm{c}}$} & 4 & 1.4 & 1.4 & 1.3 & 1.3 & 1.1 \\
\hline & 6 & 1.3 & 1.4 & 1.0 & 1.2 & 1.2 \\
\hline & 8 & 1.3 & 1.1 & 0.9 & 1.1 & 0.8 \\
\hline \multirow[t]{3}{*}{$A D G, I^{d}$} & 4 & 0.57 & 0.78 & 0.72 & 0.63 & 0.28 \\
\hline & 6 & 0.34 & 0.48 & -0.04 & 0.42 & 0.22 \\
\hline & 8 & 0.16 & 0.07 & -0.39 & 0.07 & -0.39 \\
\hline \multicolumn{7}{|c|}{$\begin{array}{l}{ }^{a} \text { Adapted from Nelson et al., Louisiana Agr. Exp. Sta. Bull. 730, October, } \\
1980 . \\
\text { b Total Digestible Nutrients, percentage of dry matter. } \\
{ }^{\mathrm{c}} \text { Quality Index. } \\
{ }^{\mathrm{d}} \text { Average daily gain, in pounds/day; feeding trial conducted with steers } \\
\text { from December through February for all hays. }\end{array}$} \\
\hline
\end{tabular}

